\title{
Diurnal pattern of nitrous oxide emissions from soils under different vertical moisture distribution conditions
}

\author{
Junzeng $\mathrm{Xu}^{{ }^{1 *}}$, Qi Wei ${ }^{2}$, Shihong Yang ${ }^{1}$, Yanhua Wang ${ }^{2}$, and Yuping Lv $^{2}$
}

\section{ABSTRACT}

The diurnal pattern of nitrous oxide $\left(\mathrm{N}_{2} \mathrm{O}\right)$ emissions is essential in understanding how weather and soil conditions influence the daily mean estimate of $\mathrm{N}_{2} \mathrm{O}$ fluxes. Incubation experiments were conducted to investigate the effects of vertical soil moisture distribution patterns on diurnal variation of $\mathrm{N}_{2} \mathrm{O}$ emissions. Clear diurnal patterns of $\mathrm{N}_{2} \mathrm{O}$ emissions on both surface watering (SW) and subsurface watering (SUW) treatments (SUW12, SUW15, and SUW18) were detected from soil sample (I), silty clay, and soil sample (II), sandy loam, where peak $\mathrm{N}_{2} \mathrm{O}$ fluxes usually occurred between 12:00 and 18:00 h. Different vertical watering patterns resulted in changes in the daily range of $\mathrm{N}_{2} \mathrm{O}$ fluxes and peak time. Mean fluxes from the SUW12, SUW15, and SUW18 treatments were $37.4 \%$, $32.7 \%$, and $43.3 \%$ lower than those from SW treatments from soil sample I, and $32.0 \%, 40.3 \%$, and $41.1 \%$ from soil sample II. Moisture distribution patterns under SUW soils could be effective to mitigate $\mathrm{N}_{2} \mathrm{O}$ emissions. The $\mathrm{N}_{2} \mathrm{O}$ emissions from soil sample I ranged from 178.3 to $2741.0 \mu \mathrm{g} \mathrm{N}_{2} \mathrm{O} \mathrm{m}^{-2} \mathrm{~h}^{-1}$, which was more than in soil sample II with 7.0 to $83.7 \mu \mathrm{g} \mathrm{N}_{2} \mathrm{O} \mathrm{m}^{-2} \mathrm{~h}^{-1}$. The different soil texture and $\mathrm{N}$ content level might account for the differences in magnitude of $\mathrm{N}_{2} \mathrm{O}$ fluxes from soils. The optimal soil moisture condition for peak $\mathrm{N}_{2} \mathrm{O}$ fluxes in the $\mathrm{SW}$ treatment had relatively narrower ranges than the SUW treatments with $46 \%$ to $60 \%$ water-filled pore space (WFPS) for soil sample I and $26 \%$ to $34 \%$ WFPS for soil sample II even though surface soil moisture for peak $\mathrm{N}_{2} \mathrm{O}$ fluxes were somewhat different from the previously reported optimal soil moisture range of $45 \%$ to $75 \%$ WFPS.

Key words: Diurnal pattern, nitrous oxide, non-uniform vertical distribution, soil moisture, water-filled pore space.

${ }^{1}$ Hohai University, State Key Laboratory of Hydrology-Water Resources and Hydraulic Engineering, 210098, Nanjing, China. "Corresponding author (xjz481@hhu.edu.cn).

${ }^{2}$ Hohai University, College of Water Conservancy and Hydropower Engineering, 210098, Nanjing, China.

Received: 19 March 2015

Accepted: 17 September 2015.

doi:10.4067/S0718-58392016000100012

\section{INTRODUCTION}

Nitrous oxide $\left(\mathrm{N}_{2} \mathrm{O}\right)$ is an important greenhouse gas that is contributing to global warming and deteriorating the atmospheric environment (IPCC, 2007; Ravishankara et al., 2009). The annual increase rate of atmospheric $\mathrm{N}_{2} \mathrm{O}$ concentration over the 1995-2005 period was higher than at any other time since instrumental monitoring began (IPCC, 2007); the atmospheric $\mathrm{N}_{2} \mathrm{O}$ concentration is projected to reach 350 to $400 \mathrm{~nL} \mathrm{~L}^{-1}$ by 2050 (FAO, 2003). Agricultural soils and soil under natural vegetation are recognized as the major source of atmospheric $\mathrm{N}_{2} \mathrm{O}$ that contribute 1.7 to $4.8 \mathrm{Tg} \mathrm{N} \mathrm{yr}^{-1}$ and 3.3 to $9.0 \mathrm{Tg} \mathrm{N} \mathrm{yr}^{-1}$, respectively, to the global atmospheric $\mathrm{N}_{2} \mathrm{O}$ budget of approximately 17.9 (8.1 to 30.7) $\mathrm{Tg} \mathrm{N} \mathrm{yr}^{-1}$ (IPCC, 2014).

The diurnal pattern of $\mathrm{N}_{2} \mathrm{O}$ emissions is essential in understanding how weather and soil conditions influence the daily mean $\mathrm{N}_{2} \mathrm{O}$ flux estimate by sampling at a specified time (Desjardins et al., 2010; Alves et al., 2012; Xia et al., 2013; van der Weerden et al., 2013). In recent years, many researchers have studied peak flux time and the most reasonable sampling time of diurnal patterns in $\mathrm{N}_{2} \mathrm{O}$ emissions. For example, Denmead et al. (1979) first found that $\mathrm{N}_{2} \mathrm{O}$ emission from a grass sward clearly showed the diurnal cycle and peak $\mathrm{N}_{2} \mathrm{O}$ emissions usually occurred in the afternoon. Liu et al. (2010) and $\mathrm{Lu}$ et al. (2010) found that $\mathrm{N}_{2} \mathrm{O}$ emissions exhibited a regular unimodal diurnal pattern with temperature changes, and maximum $\mathrm{N}_{2} \mathrm{O}$ values usually occurred at 16:00 h. Cosentino et al. (2012) indicated that $\mathrm{N}_{2} \mathrm{O}$ fluxes measured in the morning hours (09:00 to 12:00 h) were more appropriate to represent daily mean $\mathrm{N}_{2} \mathrm{O}$ fluxes. On the other hand, Xia et al. (2013) showed that sampling at 19:00 h could well represent the daily mean $\mathrm{N}_{2} \mathrm{O}$ flux from river sediment.

In addition, diurnal variation patterns and magnitude of $\mathrm{N}_{2} \mathrm{O}$ emissions from soils were mainly dominated by soil moisture content and temperature levels (Metivier et al., 2009; Tian et al., 2012; Hou et al., 2012; Kennedy et al., 2013; Wang et al., 2015; Prasad et al., 2015). All the above-mentioned studies investigated the diurnal variation of $\mathrm{N}_{2} \mathrm{O}$ emissions from soils with uniform moisture distribution (Du et al., 2006; Scheer et al., 2008), and few studies have examined the diurnal patterns of $\mathrm{N}_{2} \mathrm{O}$ emissions from soils with non-uniform moisture distribution.

It was assumed that vertical soil moisture distribution characteristics under different irrigation regimes will change $\mathrm{N}_{2} \mathrm{O}$ emission patterns from different textured soils. Therefore, $\mathrm{N}_{2} \mathrm{O}$ from two typical soils under four different vertical watering patterns (surface watering $[\mathrm{SW}]$ and subsurface watering [SUW] applied at 12,15 , and $18 \mathrm{~cm}$ below the soil surface [SUW12, SUW15, 
SUW18]) were measured in the present study, which was based on 98-d incubation experiments conducted in Nanjing, China. The objectives of this study were to reveal the impact of vertical soil moisture distribution on diurnal patterns of soil $\mathrm{N}_{2} \mathrm{O}$ emissions and investigate the difference between diurnal patterns of $\mathrm{N}_{2} \mathrm{O}$ emissions in silty clay (I) and sandy loam (II) soil samples.

\section{MATERIALS AND METHODS}

\section{Experiment site and soil description}

Experiments were conducted from April to August 2013 at the State Key Laboratory of Hydrology-Water Resources and Hydraulic Engineering in Nanjing ( $32^{\circ} 03^{\prime} \mathrm{N}, 118^{\circ} 46^{\prime}$ $\mathrm{E})$, China. The region under study has a subtropical monsoon climate with a mean annual temperature of $15.6^{\circ} \mathrm{C}$ and mean annual precipitation of $1107 \mathrm{~mm}$. Soil sample I was collected on 7 August 2012 from a plastic-covered greenhouse located at the Nanjing Vegetables Scientific Institute in Nanjing ( $31^{\circ} 56^{\prime} \mathrm{N}, 118^{\circ} 37^{\prime} \mathrm{E}$ ), China. Tomato (Solanum lycopersicum L.) was the previous crop in the greenhouse; it was transplanted on 14 April 2012 and harvested on 26 July 2012. Soil sample II was collected from a wheat (Triticum aestivum L.) field on 5 November 2012 in the suburb of Suqian, Jiangsu $\left(33^{\circ} 97^{\prime} \mathrm{N}, 118^{\circ} 28^{\prime} \mathrm{E}\right)$, China. Fertilizers were applied in the field prior to soil sample collection in accordance with local conventional fertilizer application methods at total $\mathrm{N}$ fertilizer rates of 250 and $209 \mathrm{~kg} \mathrm{~N}^{-1}$ for soil sample I (silty clay) and soil sample II (sandy loam), respectively. The upper 0-30 cm layer of soil samples I and II had organic matter content of 25.18 and $8.70 \mathrm{~g} \mathrm{~kg}^{-1}$, total $\mathrm{N}$ (TN) content of 1.40 and $0.40 \mathrm{~g} \mathrm{~kg}^{-1}$, total P (TP) content of 0.04 and $0.04 \mathrm{~g} \mathrm{~kg}^{-1}$, and $\mathrm{pH}$ of 6.24 and 7.12 , respectively. Soil samples were air-dried, ground, and sieved with a 4 $\mathrm{mm}$ sieve to remove coarse fragments. Two different bulk densities were used for packing soils to reproduce as closely as possible the surface soil conditions of the field, which are usually influenced by cultivation practices. Each soil was uniformly packed into eight soil boxes $(40 \mathrm{~cm} \times 40$ $\mathrm{cm} \times 60 \mathrm{~cm}$ ) to a bulk density of $1.25 \mathrm{~g} \mathrm{~cm}^{-3}$ for the $0-10$ $\mathrm{cm}$ surface depth and $1.33 \mathrm{~g} \mathrm{~cm}^{-3}$ for the $10-50 \mathrm{~cm}$ depth. Four osmotic pipes with an inner diameter of $6 \mathrm{~mm}$ were packed with geotextile and uniformly buried in the filtration layer, which consisted of sand and stones (10 cm thickness) at the bottom of the box to ensure uniform horizontal soil moisture distribution in the box. One end of each osmotic pipe was connected to a Mariotte bottle to form a subsurface water supply system, and the other end was connected to a drainage pipe switch. A layer of heat insulation sponge was wrapped at each side of the soil mesocosms to minimize the impact of heat transfer caused by side temperature. Soil was packed into the boxes in October 2012 and kept undisturbed for more than 4 mo before the experiments were conducted; this was to avoid the influence of soil disturbance on soil $\mathrm{N}_{2} \mathrm{O}$ emissions.

\section{Experimental design}

Two different water regimes, including SW and SUW, as well as four different watering treatments with three replicates, namely SW and SUW applied at 12, 15, and $18 \mathrm{~cm}$ below the soil surface (SUW12, SUW15, and SUW18). These were applied to the two typical soils at the beginning of the experiment to study the effects of vertical soil moisture distribution patterns under two scenarios of surface soil wetting and non-wetting on diurnal patterns of $\mathrm{N}_{2} \mathrm{O}$ emissions from different soils. The location of soil mesocosms was completely randomized and placed during the experimental process; all soil mesocosms were stored under a shelter, which was closed only on a rainy day to avoid the influence of rainfall. For the SW treatment, water was applied to the soil surface to replenish soil moisture to field capacity at the $0-50 \mathrm{~cm}$ depth. For the SUW treatments, water was supplied from the Mariotte bottle SUW supply system to saturate the subsoil at the 12-50, 15-50, and 18-50 $\mathrm{cm}$ depths. For soil sample I, water was applied at 20:00 h on 18 April at volumes of $8000,7700,8090$, and $8480 \mathrm{~mL}$ for the first watering, and at 20:00 $\mathrm{h}$ on 12 June at volumes of $7500,6930,7500$, and $7900 \mathrm{~mL}$ for the second watering. For soil sample II, water was applied at 20:00 h on 21 April at volumes of $6000,5780,6070$, and $6510 \mathrm{~mL}$ for the first watering, and at 20:00 h on 14 June at volumes of 7000, 6250,6760 , and $7190 \mathrm{~mL}$ for the second watering.

\section{Gas sampling and measurements}

To determine diurnal patterns of $\mathrm{N}_{2} \mathrm{O}$ fluxes from soil under different watering treatments, flux measurements were taken for $3 \mathrm{~d}$ from both soil samples after each watering. For soil sample I, diurnal patterns of $\mathrm{N}_{2} \mathrm{O}$ fluxes were measured on 22 April, 6 May, and 20 May after the first watering, and on 17 June, 1 July, and 22 July after the second watering. For soil sample II, they were measured on 28 April, 16 May, and 6 June after the first watering, and on 19 June, 3 July, and 24 July after the second watering. Gas samples from each mesocosm were collected with a static chamber $(40 \mathrm{~cm} \times 40 \mathrm{~cm} \times 40 \mathrm{~cm})$, which was made of 8-mm thick polyvinyl chloride (PVC). It was equipped with a thermometer to measure the air temperature inside. A rubber tube was inserted into the chamber on one side and was connected outside to a three-way stopcock used to draw air samples with a 10-mL syringe. Samples were taken at $06: 45,07: 45,09: 45,11: 45,13: 45,15: 45,17: 45,19: 45$, 21:45, 00:45, and 02:45 h on each sampling day. Four gas samples were collected from each chamber for $30 \mathrm{~min}$ at 10min intervals at each sampling time. The $\mathrm{N}_{2} \mathrm{O}$ concentrations were analyzed with a gas chromatography system (Agilent 7890A, Agilent Technologies, Santa Clara, California, USA) with an electron capture detector (ECD), and $\mathrm{N}_{2} \mathrm{O}$ fluxes were calculated in accordance with the linear $\mathrm{N}_{2} \mathrm{O}$ concentration increase rate within the chamber (Hou et al., 2012). All samples cannot be analyzed within $48 \mathrm{~h}$, the time usually considered as the best analysis period by the gas 
chromatography (GC) system, so two of the three sample replicates were analyzed; the third replicate was analyzed only when the results of the previous two samples exhibited large variations. The $\mathrm{N}_{2} \mathrm{O}$ fluxes were calculated as the mean of the two replicates and daily mean $\mathrm{N}_{2} \mathrm{O}$ fluxes were calculated by integrating hourly $\mathrm{N}_{2} \mathrm{O}$ fluxes .

Temperatures inside and outside the chamber were also measured with mercury thermometers during $\mathrm{N}_{2} \mathrm{O}$ emission monitoring. Soil samples (approximately 2-3 g) from the upper 0-24 $\mathrm{cm}$ soil layer (every $4 \mathrm{~cm}$ vertically) were collected through holes (20 $\mathrm{mm}$ in diameter) in the soil box with stainless steel samplers (18 $\mathrm{mm}$ in diameter) at 09:45 $\mathrm{h}$, and they were refilled every two or three samplings with soil having approximately the same moisture content. Soil moisture contents were determined through oven-drying at $105{ }^{\circ} \mathrm{C}$ for $24 \mathrm{~h}$. The water-filled pore space (WFPS) was calculated as the ratio of soil volumetric content to total soil porosity; particle density was assumed to be $2.65 \mathrm{~g} \mathrm{~cm}^{-3}$ (Beare et al., 2009).

\section{Statistical analysis}

Statistical analyses were performed with Origin 8.5 (OriginLab Corporation, Northampton, Massachusetts, USA) software for Windows and Excel 2003 (Microsoft, Redmond, Washington, USA). Fisher's least significant difference (LSD) tests were performed to detect the difference in $\mathrm{N}_{2} \mathrm{O}$ fluxes between SW and SUW treatments at certain observation times. For all the statistical analyses, $\mathrm{p} \geqq 0.10,0.05<\mathrm{p}<0.10$, and $\mathrm{p}<0.05$ levels were considered to be nonsignificant, slightly significant, and significant, respectively (Yao et al., 2010).

\section{RESULTS AND DISCUSSION}

\section{Air temperature}

The air temperatures on the sampling dates are listed in Table 1. On 22 April, 6 May, 20 May, 17 June, 1 July, and 22 July, air temperatures ranged from 8.2 to $15.6,15.9$ to $20.1,19.8$ to $30.5,29.0$ to $37.6,27.7$ to 35.9 , and 26.7 to $31.7^{\circ} \mathrm{C}$ with mean values of $12.0,18.5,26.1,34.1,32.1$, and $29.4^{\circ} \mathrm{C}$, respectively. Temperatures ranging from 21.8 to $31.9,14.9$ to $18.9,24.8$ to $32.1,24.1$ to $31.3,31.1$ to 36.7 , and 30.0 to $36.8^{\circ} \mathrm{C}$ were taken on 28 April, 16 May, 6 June, 19 June, 3 July, and 24 July with mean values of $27.3,16.9,28.6,27.9,33.7$, and $33.3^{\circ} \mathrm{C}$, respectively. The maximum temperatures usually occurred at 12:00, 14:00, and 16:00 h, except for 16 May and 22 July that were rainy.

\section{Diurnal pattern of $\mathrm{N}_{2} \mathrm{O}$ emissions from soil sample I}

Diurnal patterns and ranges of $\mathrm{N}_{2} \mathrm{O}$ fluxes from soil sample I differed among watering treatments or sampling dates (Figure 1). For the $\mathrm{SW}$ treatment, $\mathrm{N}_{2} \mathrm{O}$ emission fluxes increased when soil moisture decreased. Fluxes mainly ranged from 1324.6 to $1810.5 \mu \mathrm{g} \mathrm{N}_{2} \mathrm{O} \mathrm{m} \mathrm{m}^{-2} \mathrm{~h}^{-1}$ and 1447.4 to $2591.9 \mu \mathrm{g} \mathrm{N}_{2} \mathrm{O} \mathrm{m}^{-2} \mathrm{~h}^{-1}$ on 22 April and 6 May with mean values of 1626.9 and $1915.5 \mu \mathrm{g} \mathrm{N}_{2} \mathrm{O} \mathrm{m}{ }^{-2} \mathrm{~h}^{-1}$, respectively

Table 1. Air temperatures on sampling dates.

\begin{tabular}{|c|c|c|c|c|c|c|c|}
\hline Soil texture & Temperature $\left({ }^{\circ} \mathrm{C}\right)$ & $22 \mathrm{Apr}$ & 6 May & 20 May & 17 June & 1 July & 22 July \\
\hline \multirow[t]{4}{*}{ Soil sample I } & Max (time) & $15.6(12: 00)$ & $20.1(14: 00)$ & $30.5(16: 00)$ & $37.6(14: 00)$ & $35.9(16: 00)$ & $31.7(18: 00)$ \\
\hline & Min & 8.2 & 15.9 & 19.8 & 29.0 & 27.7 & 26.7 \\
\hline & Mean & 12.0 & 18.5 & 26.1 & 34.1 & 32.1 & 29.4 \\
\hline & & $28 \mathrm{Apr}$ & 16 May & 6 June & 19 June & 3 July & 24 July \\
\hline \multirow[t]{3}{*}{ Soil sample II } & Max (time) & $31.9(14: 00)$ & $18.9(7: 00)$ & $32.1(14: 00)$ & $31.3(12: 00)$ & $36.7(14: 00)$ & $36.8(14: 00)$ \\
\hline & Min & 21.8 & 14.9 & 24.8 & 24.1 & 31.1 & 30.0 \\
\hline & Mean & 27.3 & 16.9 & 28.6 & 27.9 & 33.7 & 33.3 \\
\hline
\end{tabular}

Figure 1. Diurnal variation of $\mathrm{N}_{2} \mathrm{O}$ emissions from soil sample $\mathrm{I}$ at different sampling dates.
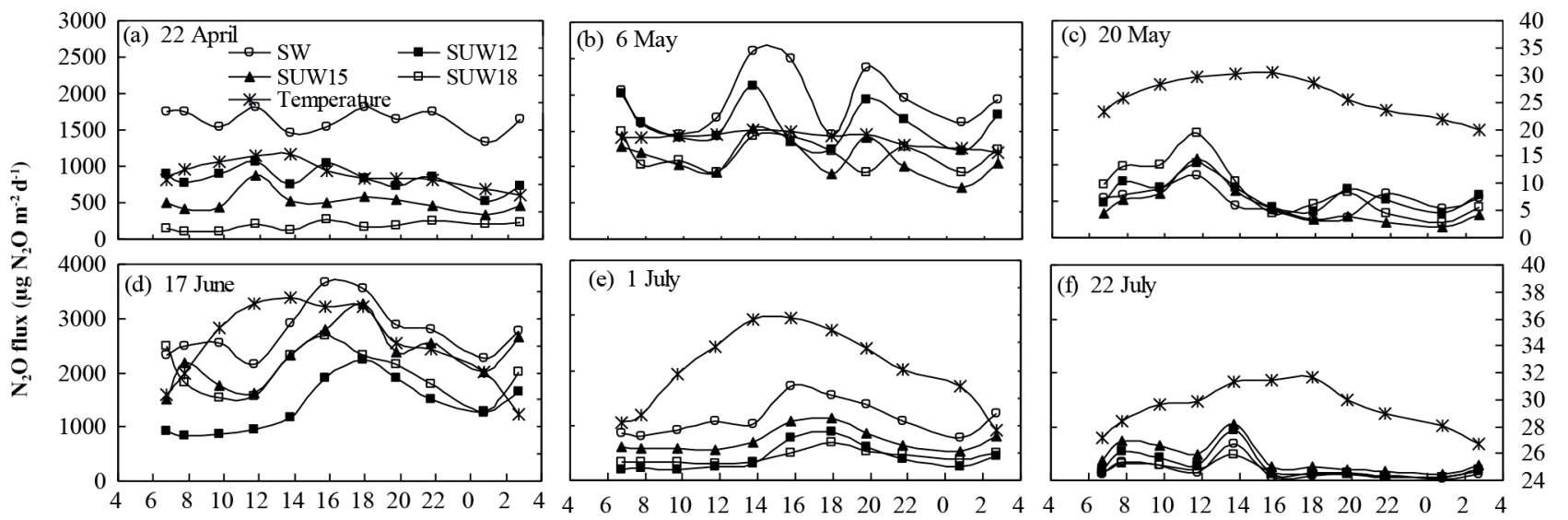
(Figures 1a and 1b), which were 2.3 and 2.9 times higher than those on 20 May (Figure 1c). The lower flux on 20 May might be attributable to the slow soil moisture depletion rate during this period (Hou et al., 2012). The diurnal variations of $\mathrm{N}_{2} \mathrm{O}$ emissions on 22 April, 6 May, and 20 May showed a bimodal curve, but the peak time of emergence was not fixed. The peaks sometimes appeared at 12:00 $\mathrm{h}$ and sometimes at 14:00, 16:00, and 20:00 h. Results indicated that the peak time of $\mathrm{N}_{2} \mathrm{O}$ emissions mostly depends on variations in soil moisture and changes in temperature (Hou et al., 2012; Trost et al., 2015). Fluxes in the evening or early morning were generally lower than during the day with small peaks usually at 03:00 h, which were still lower than in the daytime. The $\mathrm{N}_{2} \mathrm{O}$ emissions from the SUW (SUW12, SUW15, and SUW18) treatments followed a similar diurnal pattern always with two peaks at 12:00 and 20:00 h. The $\mathrm{N}_{2} \mathrm{O}$ fluxes from the SUW12, SUW15, and SUW18 treatments on 22 April ranged from 521.8 to 1057.6, 341.9 to 872.3, and 96.9 to $264.2 \mu \mathrm{g} \mathrm{N}_{2} \mathrm{O} \mathrm{m} \mathrm{m}^{-2} \mathrm{~h}^{-1}$ along with daily mean values of 810.3, 505.6, and $184.3 \mu \mathrm{g} \mathrm{N}_{2} \mathrm{O} \mathrm{m}^{-2} \mathrm{~h}^{-1}$, respectively (Figure 1a). Mean $\mathrm{N}_{2} \mathrm{O}$ fluxes increased by $97.1 \%, 118.8 \%$, and $537.4 \%$ in the SUW12, SUW15, and SUW18 treatments on 6 May (Figure 1b) compared with the values on 22 April. However, a single daily peak in $\mathrm{N}_{2} \mathrm{O}$ flux variation was observed for all treatments after the second watering. These results suggested that the problem of the diurnal variation curve in $\mathrm{N}_{2} \mathrm{O}$ emissions was rather complicated, and results were simultaneously affected by multiple factors, such as meteorological factors, soil microorganisms, and soil moisture (Kallenbach et al., 2010; Yamamoto et al., 2012; Trost et al., 2015). For the SW treatment, peaks appeared at 16:00 and 18:00 h on 17 June and 1 July, and at 14:00 h on 22 July (Figures 1d, 1e, and 1f). Mean flux on 1 July (1110.1 $\mu \mathrm{g}$ $\left.\mathrm{N}_{2} \mathrm{O} \mathrm{m}^{-2} \mathrm{~h}^{-1}\right)$ was much lower than on 17 June $\left(2741.0 \mu \mathrm{g} \mathrm{N}_{2} \mathrm{O}\right.$ $\mathrm{m}^{-2} \mathrm{~h}^{-1}$ ), which might be attributable to the low soil moisture content on 1 July that inhibited the nitrifying activity (Wang et al., 2010; Horváth et al., 2010; Tian et al., 2012). For the
SUW treatments, $\mathrm{N}_{2} \mathrm{O}$ fluxes followed a diurnal pattern similar to the SW treatment with peak fluxes of 2242.6, 3261.0 , and $2678.1 \mathrm{gg} \mathrm{N}_{2} \mathrm{O} \mathrm{m}^{-2} \mathrm{~h}^{-1}$ for the SUW12, SUW15, and SUW18 treatments, respectively, on 17 June (Figure 1d). However, peak $\mathrm{N}_{2} \mathrm{O}$ fluxes in the SUW treatments mostly ranged from 679.0 to 1127.0 and 486.1 to $1030.3 \mu \mathrm{g} \mathrm{N}_{2} \mathrm{O}$ $\mathrm{m}^{-2} \mathrm{~h}^{-1}$ on 1 July and 22 July, respectively (Figures 1e and 1f). These were much lower than the peak fluxes on 17 June. The high $\mathrm{N}_{2} \mathrm{O}$ peak emission on 17 June can be attributed to the higher temperature and the faster soil moisture depletion rate, which can increase $\mathrm{C}$ and $\mathrm{N}$ availability and promote the soil nitrification and denitrification reaction (Kallenbach et al., 2010; Pfab et al., 2012; Yamamoto et al., 2012; Hou et al., 2012). Overall, mean $\mathrm{N}_{2} \mathrm{O}$ fluxes from the SUW12, SUW15, and SUW18 treatments were $37.4 \%, 32.7 \%$, and $43.3 \%$ lower than those from the SW treatments after two waterings. Results also implied that the moisture distribution patterns in SUW soils could effectively mitigate $\mathrm{N}_{2} \mathrm{O}$ emissions.

Daily mean $\mathrm{N}_{2} \mathrm{O}$ fluxes from soil I were generally $\mathrm{SW}$ $>$ SUW12 $>$ SUW18 $>$ SUW15 on 22 April, 6 May, and 20 May (Table 2). Mean $\mathrm{N}_{2} \mathrm{O}$ fluxes from all the $\mathrm{SUW}$ treatments were significantly lower than those from the SW treatments on 22 April; they were significantly lower from the SUW15 and SUW18 soils than from the SW soil on 6 May and 20 May $(P<0.05)$. However, $\mathrm{N}_{2} \mathrm{O}$ fluxes from soil I on 17 June, 1 July, and 22 July were $\mathrm{SW}>\mathrm{SUW} 15$ $>$ SUW18 $>$ SUW12 where $\mathrm{N}_{2} \mathrm{O}$ emissions from the SW treatment were significantly higher than from the SUW12 and SUW18 treatments $(P<0.05)$. Daily mean $\mathrm{N}_{2} \mathrm{O}$ fluxes from all the SUW treatments were significantly lower than from the SW treatments on 17 June and 1 July, but mean $\mathrm{N}_{2} \mathrm{O}$ fluxes from the SUW12 and SUW15 treatments were significantly higher than those from the SW treatment on 22 July.

For the $\mathrm{SW}$ treatment, the daily mean $\mathrm{N}_{2} \mathrm{O}$ flux on 20 May was significantly lower than on 22 April and 6 May (Table 2),

Table 2. Mean $\mathrm{N}_{2} \mathrm{O}$ fluxes from different soils on different sampling dates.

\begin{tabular}{|c|c|c|c|c|c|c|}
\hline \multirow{2}{*}{$\begin{array}{l}\text { Soil } \\
\text { Sample }\end{array}$} & \multirow[b]{2}{*}{ Watering } & \multirow{2}{*}{$\begin{array}{l}\text { Observation } \\
\text { stages }\end{array}$} & \multicolumn{4}{|c|}{ Daily mean $\mathrm{N}_{2} \mathrm{O}$ emissions $\left(\mu \mathrm{g} \mathrm{N}_{2} \mathrm{O} \mathrm{m}^{-2} \mathrm{~h}^{-1}\right)$} \\
\hline & & & SW & SUW12 & SUW15 & SUW18 \\
\hline \multirow[t]{6}{*}{ Soil I } & First watering & 22-Apr & $1626.89 \pm 81.34 \mathrm{aA}(63.4 \%)$ & $810.28 \pm 40.51 \mathrm{bA}(58.4 \%)$ & $505.63 \pm 25.28 \mathrm{cA}(55.2 \%)$ & $184.29 \pm 9.21 \mathrm{dA}(53.3 \%)$ \\
\hline & & 6-May & $1915.50 \pm 95.77 \mathrm{aA}(54.3 \%)$ & $1596.72 \pm 79.84 \mathrm{bB}(51.7 \%)$ & $1106.27 \pm 55.31 \mathrm{cdB}(48.7 \%)$ & $1174.65 \pm 58.73 \mathrm{~dB}(47.1 \%)$ \\
\hline & & 20-May & $497.18 \pm 24.86 \mathrm{aB}(41.9 \%)$ & $589.73 \pm 29.49 \mathrm{acA}(44.4 \%)$ & $423.31 \pm 21.17 \mathrm{bA}(43.9 \%)$ & $639.13 \pm 31.96 \mathrm{cC}(41.5 \%)$ \\
\hline & Second watering & 17-Jun & $2740.97 \pm 137.05 \mathrm{aA}(54.3 \%)$ & $1388.75 \pm 69.44 \mathrm{bA}(54.2 \%)$ & $2285.67 \pm 114.28 \mathrm{cdA}(53.2 \%)$ & $1966.49 \pm 98.32 \mathrm{dA}(53.0 \%)$ \\
\hline & & 1-Jul & $1110.05 \pm 55.50 \mathrm{aB}(44.8 \%)$ & $404.91 \pm 20.25 \mathrm{bdBC}(44.4 \%)$ & $719.82 \pm 35.99 \mathrm{cB}(43.7 \%)$ & $426.83 \pm 21.34 \mathrm{dBC}(42.8 \%)$ \\
\hline & & 22-Jul & $178.28 \pm 8.91 \mathrm{aC}(36.7 \%)$ & $261.82 \pm 13.09 \mathrm{bC}(38.2 \%)$ & $390.21 \pm 19.51 \mathrm{cC}(38.5 \%)$ & $186.03 \pm 9.30 \mathrm{aC}(35.9 \%)$ \\
\hline \multirow[t]{6}{*}{ Soil II } & First watering & 28-Apr & $23.95 \pm 1.20 \mathrm{aA}(31.3 \%)$ & $19.88 \pm 0.99 \mathrm{bcdA}(35.4 \%)$ & $17.92 \pm 1.27 \mathrm{cdA}(36.3 \%)$ & $16.04 \pm 0.80 \mathrm{dA}(36.0 \%)$ \\
\hline & & 16-May & $17.70 \pm 0.89 \mathrm{aB}(24.6 \%)$ & $11.54 \pm 0.58 \mathrm{bBC}(28.1 \%)$ & $7.07 \pm 0.35 \mathrm{cdBC}(28.7 \%)$ & $7.03 \pm 0.35 \mathrm{dBC}(29.0 \%)$ \\
\hline & & 6-Jun & $11.67 \pm 0.58 \mathrm{aC}(12.3 \%)$ & $9.09 \pm 0.46 \mathrm{bcdC}(19.6 \%)$ & $7.85 \pm 0.40 \mathrm{cdC}(19.8 \%)$ & $8.14 \pm 0.41 \mathrm{dC}(19.5 \%)$ \\
\hline & Second watering & 19-Jun & $83.69 \pm 4.19 \mathrm{aA}(29.1 \%)$ & $61.99 \pm 3.10 \mathrm{bcA}(30.0 \%)$ & $50.78 \pm 2.54 \mathrm{cdA}(30.7 \%)$ & $46.35 \pm 2.32 \mathrm{dA}(31.0 \%)$ \\
\hline & & 3-Jul & $22.49 \pm 1.13 \mathrm{aBC}(17.4 \%)$ & $14.24 \pm 0.72 \mathrm{bcdBC}(20.8 \%)$ & $17.23 \pm 0.87 \mathrm{cdB}(22.4 \%)$ & $15.92 \pm 0.80 \mathrm{~dB}(21.5 \%)$ \\
\hline & & 24-Jul & $12.12 \pm 0.61 \mathrm{aC}(7.3 \%)$ & $9.41 \pm 0.47 \mathrm{bcdC}(14.1 \%)$ & $9.46 \pm 0.48 \mathrm{cdC}(13.7 \%)$ & $7.56 \pm 0.38 \mathrm{dC}(14.9 \%)$ \\
\hline
\end{tabular}

SW: Surface watering, SUW12, SUW15, and SUW18: subsurface water applied at 12, 15, and 18 cm below soil surface, respectively, WFPS: water-filled pore space.

Different lower case letters in each row represent significant differences between different treatments at $\mathrm{p}=0.05$.

Different uppercase letters in each column represent significant differences between different sampling dates after each watering at $\mathrm{p}=0.05$. The data inside the brackets represent the mean of WFPS in the $0-12 \mathrm{~cm}$ soil depth. 
and a significant difference was found among $\mathrm{N}_{2} \mathrm{O}$ fluxes on 17 June and those found on 1 July and 22 July. Significant differences were also found between $\mathrm{N}_{2} \mathrm{O}$ fluxes on 6 May and on 22 April or 20 May for the SUW18 treatments. For the SUW12 and SUW15 treatments, fluxes on 6 May were significantly higher than on 22 April and 20 May $(\mathrm{P}<0.05)$. In addition, $\mathrm{N}_{2} \mathrm{O}$ fluxes for all the SUW treatments on 17 June were significantly higher than on 1 July and 22 July $(\mathrm{P}<0.05)$, but no difference was found between $\mathrm{N}_{2} \mathrm{O}$ fluxes from the SUW12 and SUW18 treatments on 1 July and 22 July. On the whole, diurnal variation patterns and magnitude of $\mathrm{N}_{2} \mathrm{O}$ emissions from the SUW treatments were somewhat different from the SW treatment after both waterings; this agrees with earlier studies by Metivier et al. (2009) and Tian et al. (2012), who stated that $\mathrm{N}_{2} \mathrm{O}$ emissions from soils were mainly dominated by soil moisture content and temperature levels.

\section{Diurnal pattern of $\mathrm{N}_{2} \mathrm{O}$ emissions from soil sample II}

For soil sample II, the diurnal $\mathrm{N}_{2} \mathrm{O}$ fluxes patterns from $\mathrm{SW}$ soil on all the sampling dates showed a bimodal curve with peaks appearing at 12:00 and 16:00 h (Figure 2). The $\mathrm{N}_{2} \mathrm{O}$ emissions were generally reduced with a decrease in soil moisture from 28 April to 16 May and 6 June. Fluxes mostly ranged from 20 to $100 \mu \mathrm{g} \mathrm{N}_{2} \mathrm{O} \mathrm{m}^{-2} \mathrm{~h}^{-1}$ with daily means of 24.0, 17.7, and $11.7 \mu \mathrm{g} \mathrm{N}_{2} \mathrm{O} \mathrm{m}^{-2} \mathrm{~h}^{-1}$ on 28 April, 16 May, and 6 June, respectively. The peak $\mathrm{N}_{2} \mathrm{O}$ flux $\left(178.6 \mu \mathrm{g} \mathrm{N}_{2} \mathrm{O}\right.$ $\mathrm{m}^{-2} \mathrm{~h}^{-1}$ ) on 19 June was the highest of all the sampling dates and was much lower than the corresponding flux from soil sample I. This is attributable to the differences in soil texture and $\mathrm{N}$ levels. Heavy-textured soils frequently produce higher $\mathrm{N}_{2} \mathrm{O}$ fluxes than light soils (Liu et al., 2008), and $\mathrm{N}_{2} \mathrm{O}$ fluxes from clay soils are often higher than those from sandy or loam soils (Liu et al., 2008; Trost et al., 2015). The texture of soil samples I and II was silty clay and sandy loam with total $\mathrm{N}$ content of 1.4 and $0.4 \mathrm{~g} \mathrm{~kg}^{-1}$, respectively. As a result, the peak $\mathrm{N}_{2} \mathrm{O}$ flux from soil I was much higher than from soil sample II. For the SUW treatments, some differences were found in diurnal patterns between $\mathrm{N}_{2} \mathrm{O}$ flux after the first and second waterings where two peaks and one peak were observed after the first and second waterings, respectively (Figure 2). Peak values always appeared at 12:00 and 16:00 $\mathrm{h}$ after the first watering, and at approximately 14:00 $h$ after the second watering. The daily mean $\mathrm{N}_{2} \mathrm{O}$ fluxes from the SUW12, SUW15, and SUW18 treatments on 28 April were $19.9,17.9$, and $16.0 \mu \mathrm{g} \mathrm{N}_{2} \mathrm{O} \mathrm{m} \mathrm{m}^{-2} \mathrm{~h}^{-1}$, which were $72.4 \%, 153.5 \%$, and $128.1 \%$ higher than on 16 May (Figure 2b). The $\mathrm{N}_{2} \mathrm{O}$ fluxes observed at 18:00 and 22:00 $\mathrm{h}$ on 16 May were negative, indicating that the soil can act as a sink for atmospheric $\mathrm{N}_{2} \mathrm{O}$. Mean $\mathrm{N}_{2} \mathrm{O}$ fluxes on 6 June were generally less than $10 \mu \mathrm{g} \mathrm{N}_{2} \mathrm{O} \mathrm{m}^{-2} \mathrm{~h}^{-1}$ (9.1, 7.9, and $8.1 \mu \mathrm{g} \mathrm{N}_{2} \mathrm{O} \mathrm{m}^{-2} \mathrm{~h}^{-1}$ from the SUW12, SUW15, and SUW18 treatments, respectively) (Figure 2c). Maximum $\mathrm{N}_{2} \mathrm{O}$ fluxes for all the sampling dates were measured as 116.1, 105.3, and $143.1 \mu \mathrm{g} \mathrm{N}_{2} \mathrm{O} \mathrm{m} \mathrm{m}^{-2} \mathrm{~h}^{-1}$ for the SUW12, SUW15, and SUW18 treatments, respectively, on 19 June (Figure 2d). Peak $\mathrm{N}_{2} \mathrm{O}$ fluxes generally occurred during the daytime, but with a significant variation in peak times among different sampling dates. Furthermore, peak $\mathrm{N}_{2} \mathrm{O}$ fluxes on most of the sampling dates did not match the highest daily temperature. Liu et al. (2010) and Qiu et al. (2011) also reported that peak $\mathrm{N}_{2} \mathrm{O}$ emissions always appeared 1 to $3 \mathrm{~h}$ after the maximum temperature. This was mainly because the diurnal variation of $\mathrm{N}_{2} \mathrm{O}$ emissions was also affected by other factors, such as soil aeration condition, carbohydrate availability, and bacteria activity in addition to temperature and a slight change in soil moisture during a single sampling date (Xie and Li, 2005; Tian et al., 2012; Cai et al., 2012; Kumar et al., 2014; Keil et al., 2015). Mean $\mathrm{N}_{2} \mathrm{O}$ fluxes from the SUW12, SUW15, and SUW18 treatments were $32.0 \%, 40.3 \%$, and $41.1 \%$ lower than from the SW treatments after two waterings.

For soil sample II, $\mathrm{N}_{2} \mathrm{O}$ fluxes from different treatments on all sampling dates were $\mathrm{SW}>\mathrm{SUW} 12>\mathrm{SUW} 15>$ $\mathrm{SUW} 18$. The daily mean $\mathrm{N}_{2} \mathrm{O}$ fluxes from the $\mathrm{SW}$ treatment on all the sampling dates were significantly higher than the SUW treatments $(\mathrm{P}<0.05)$ (Table 2$)$, while nonsignificant differences were found among $\mathrm{N}_{2} \mathrm{O}$ fluxes from different SUW treatments. For the SW treatment, mean $\mathrm{N}_{2} \mathrm{O}$ fluxes

Figure 2. Diurnal variation of $\mathrm{N}_{2} \mathrm{O}$ emissions from soil sample II at different sampling dates.
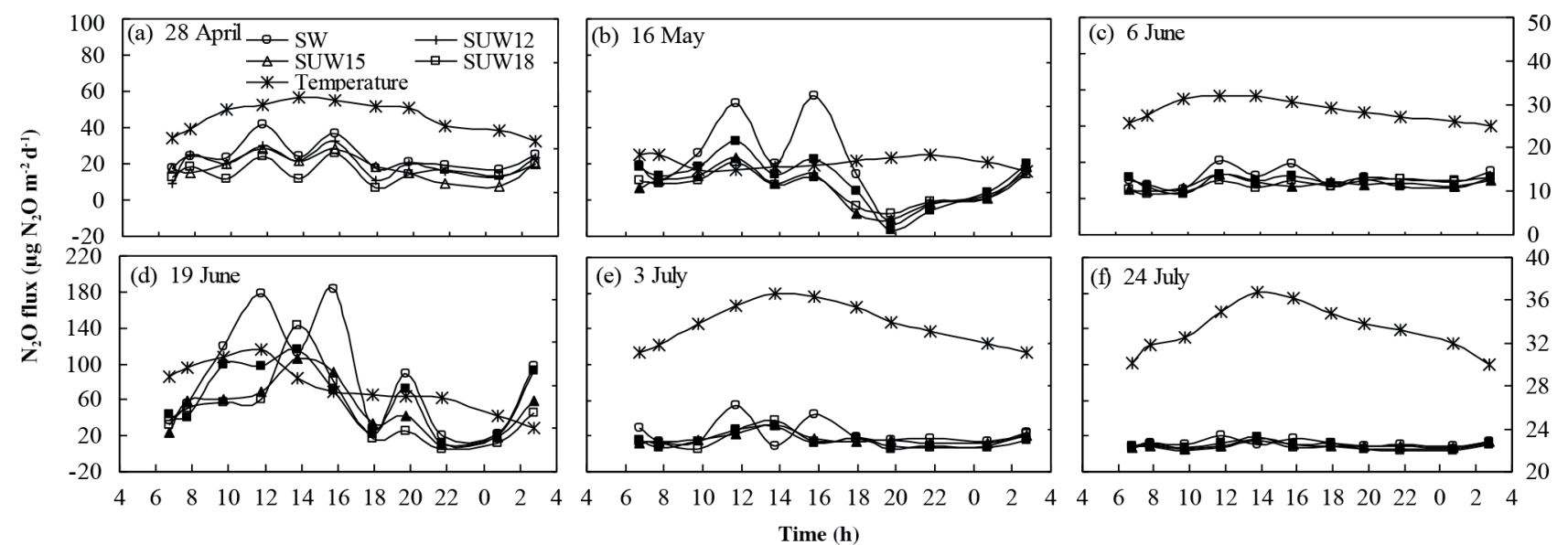
on 28 April were significantly higher than on 16 May or 6 June, and mean fluxes on 19 June were significantly higher than on 3 July or 24 July $(P<0.05)$. For the SUW treatments, mean fluxes on 6 June were significantly lower than the corresponding fluxes on 28 April, but there were no differences between the fluxes on 16 May and 6 June. In addition, fluxes from the SUW 15 and SUW 18 treatments on 19 June were significantly higher than on 3 July or 24 July, and there were no differences between $\mathrm{N}_{2} \mathrm{O}$ emissions from the SUW12 treatment on 3 July and 24 July.

\section{Effect of soil moisture on $\mathrm{N}_{2} \mathrm{O}$ emissions}

Soil moisture values for soil sample I on different sampling dates are shown in Figure 2. For the SW treatment, WFPS at the $0-12 \mathrm{~cm}$ soil depth was mostly maintained from $47 \%$ to $71 \%, 33 \%$ to $70 \%$, and $27 \%$ to $52 \%$ on 22 April, 6 May, and 20 May, respectively. The corresponding $\mathrm{N}_{2} \mathrm{O}$ emissions first increased and then decreased gradually on these sampling dates (Figures 1a, 1b, and 1c). Daily mean $\mathrm{N}_{2} \mathrm{O}$ fluxes were 1626.9 and $1915.5 \mu \mathrm{g} \mathrm{N}_{2} \mathrm{O} \mathrm{m} \mathrm{m}^{-2} \mathrm{~h}^{-1}$ on 22 April and 6 May, respectively, and they were $227.2 \%$ and $285.3 \%$ higher than fluxes on 20 May. High temperature and the soil water evaporation rate might have contributed to high $\mathrm{N}_{2} \mathrm{O}$ emissions on 22 April and 6 May. The WFPS at the 0-12 $\mathrm{cm}$ soil depth on 17 June, 1 July, and 22 July was $46 \%$ to $59 \%, 26 \%$ to $60 \%$, and $20 \%$ to $47 \%$, respectively, but $\mathrm{N}_{2} \mathrm{O}$ fluxes decreased gradually on these dates perhaps because $\mathrm{N}_{2} \mathrm{O}$ emissions increased with increased soil moisture within a certain range of soil WFPS (Peng et al., 2009; Pimentel et al., 2015) (Figures 1d, 1e, and 1f). The maximum $\mathrm{N}_{2} \mathrm{O}$ flux (3677.4 $\left.\mu \mathrm{g} \mathrm{N}_{2} \mathrm{O} \mathrm{m}^{-2} \mathrm{~h}^{-1}\right)$ was observed on 17 June when WFPS (46\% to $59 \%$ ) at the $0-12 \mathrm{~cm}$ soil depth was within the reported optimal soil WFPS range (45\% to $75 \%$ ) for peak
$\mathrm{N}_{2} \mathrm{O}$ emissions (Bateman and Baggs, 2005; Khalil and Baggs, 2005; Sey et al., 2008; Castellano et al., 2010; Laville et al., 2011). Simultaneously, the daily mean temperature of 34.1 ${ }^{\circ} \mathrm{C}$ was also within the reported optimum temperature range (25 to $35^{\circ} \mathrm{C}$ ) for the high nitrification and denitrification reaction (Liu and Zhao, 2008). On 20 May, soil WFPS at the $0-8 \mathrm{~cm}$ soil depth $(27 \%$ to $43 \%)$ was lower than the $45 \%$ to $75 \%$ range, and $\mathrm{N}_{2} \mathrm{O}$ emissions were quite different from those on 20 May and 22 April. Similarly, low WFPS in surface soils on 1 July ( $33 \%$ to $43 \%$ at $0-4 \mathrm{~cm}$ soil depth) and 22 July ( $20 \%$ to $43 \%$ at $0-8 \mathrm{~cm}$ soil depth) might have led to the difference in $\mathrm{N}_{2} \mathrm{O}$ emissions on both dates as compared with $\mathrm{N}_{2} \mathrm{O}$ emissions on 17 June.

For the SUW treatments, soil WFPS at the $0-12 \mathrm{~cm}$ soil depth was maintained from $33 \%$ to $69 \%, 24 \%$ to $64 \%, 20 \%$ to $58 \%, 45 \%$ to $64 \%, 26 \%$ to $60 \%$, and $19 \%$ to $56 \%$ on 22 April, 6 May, 20 May, 17 June, 1 July, and 22 July, respectively. The $\mathrm{N}_{2} \mathrm{O}$ emissions for all the SUW treatments showed a bimodal diurnal curve pattern on 22 April, 6 May, and 20 May with peaks appearing mainly at 12:00 and 20:00 h (Figures 1a, 1b, and $1 \mathrm{c}$ and Figures $3 \mathrm{a}, 3 \mathrm{~b}, 3 \mathrm{c}$, and $3 \mathrm{~d}$ ). It was confirmed that peak $\mathrm{N}_{2} \mathrm{O}$ fluxes frequently appeared when soil moisture was appropriate and the temperature was high (Qiu et al., 2011; Emery and Mosier, 2015; Trost et al., 2015). The maximum $\mathrm{N}_{2} \mathrm{O}$ fluxes on all sampling dates were 2242.6, 3261.0, and $2678.1 \mu \mathrm{g} \mathrm{N}_{2} \mathrm{O} \mathrm{m}^{-2} \mathrm{~h}^{-1}$ for the SUW12, SUW15, and SUW18 treatments, respectively, which were measured on 17 June when soil WFPS at the $0-12 \mathrm{~cm}$ depth ranged from $45 \%$ to $64 \%$. The WFPS range in the SUW treatment for peak $\mathrm{N}_{2} \mathrm{O}$ fluxes was also within the reported optimal soil WFPS range for peak $\mathrm{N}_{2} \mathrm{O}$ emissions, but was slightly different than the SW treatment (46\% to $59 \%$ ).

Moisture contents in soil sample II ( $2 \%$ to $42 \%$ WFPS) were much lower than in soil sample I (16\% to $73 \%$ WFPS)

Figure 3. Moisture in surface watering (SW) and subsurface watering (SUW) treatments from soil I at different observation stages.

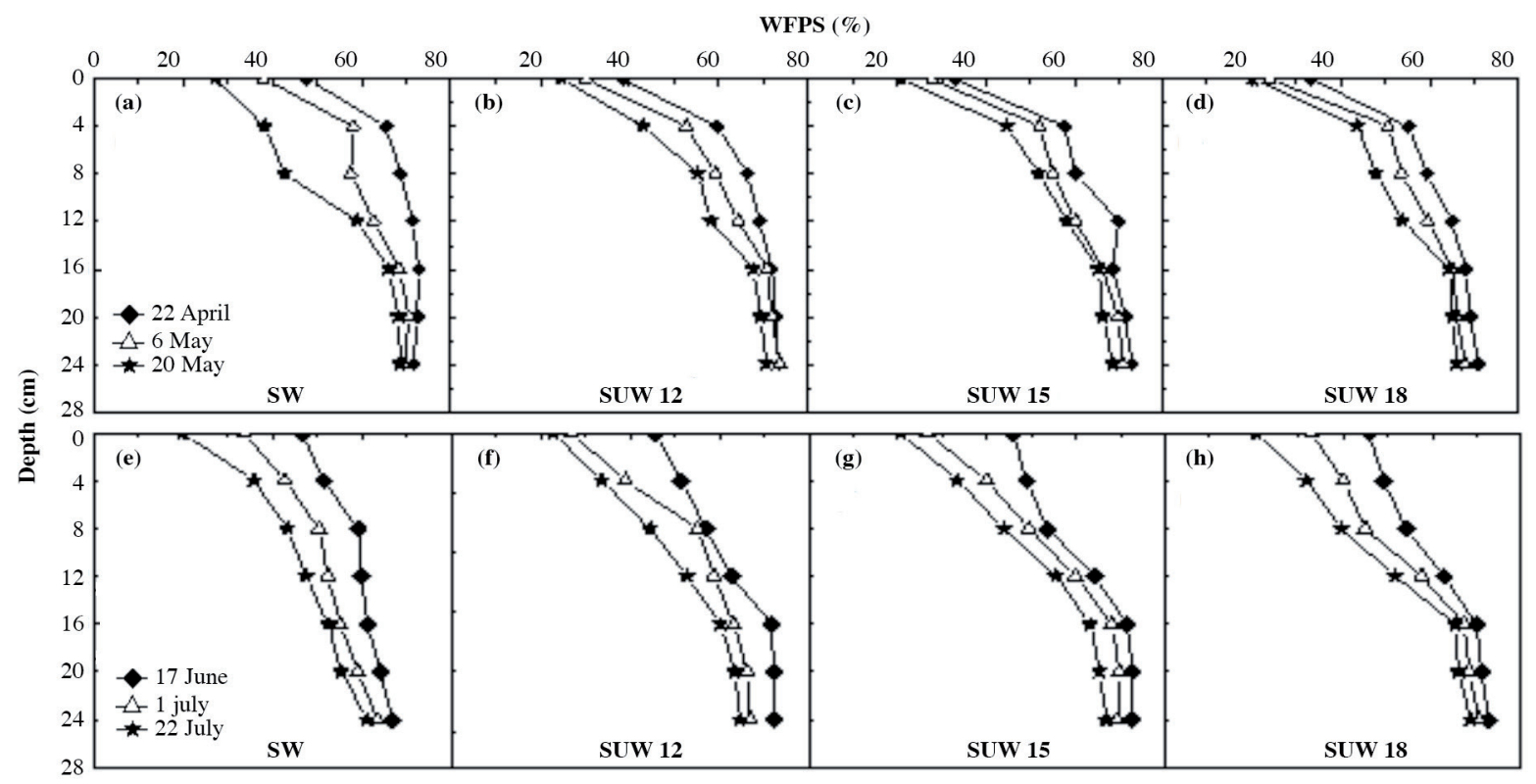

WFPS: Water-filled pore space. 
Figure 4. Moisture in surface watering (SW) and subsurface watering (SUW) treatments from soil II at different observation stages.

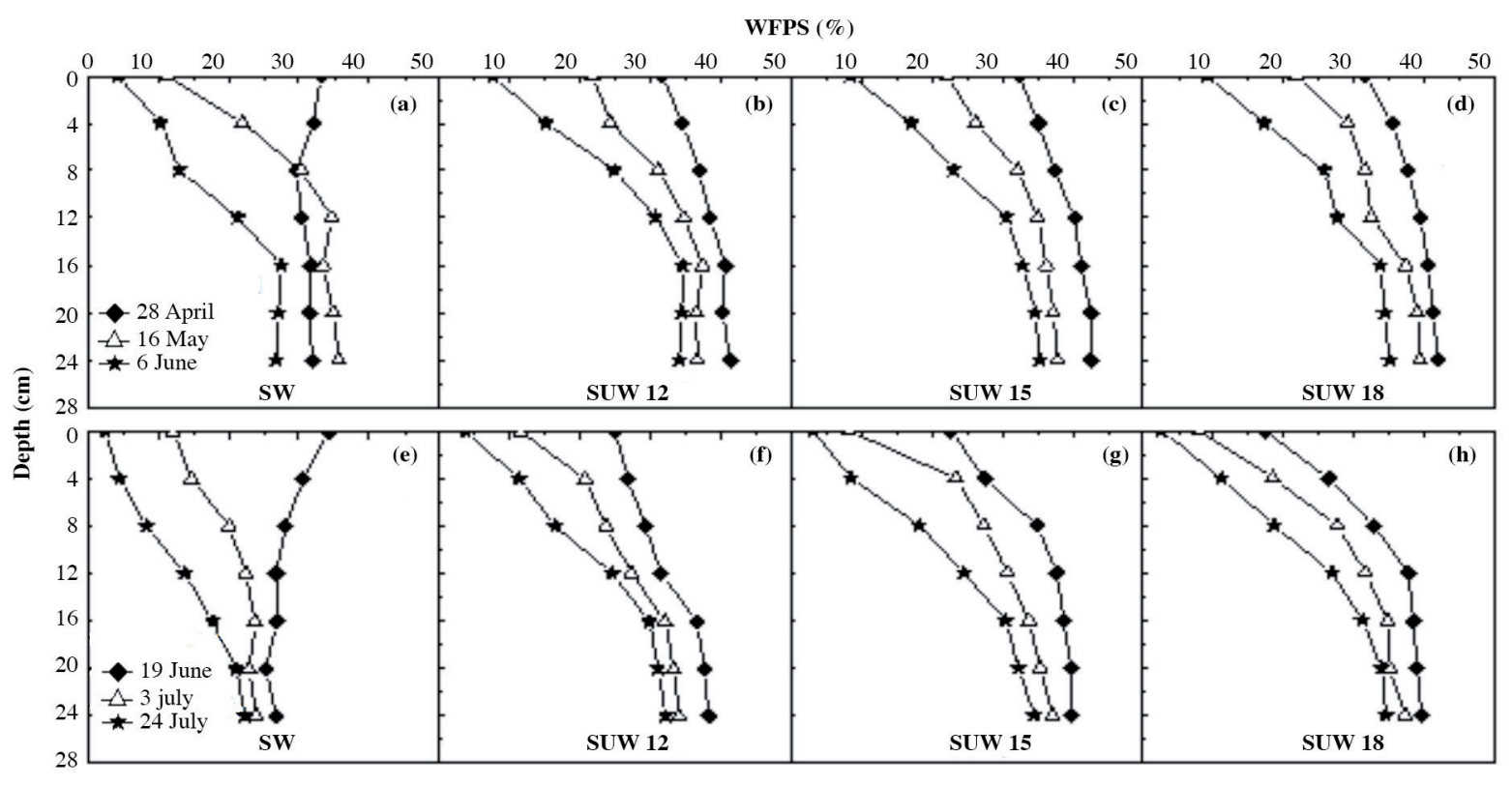

WFPS: Water-filled pore space.

(Figure 4). For the SW treatment, WFPS at the $0-12 \mathrm{~cm}$ soil depth was mostly maintained at $31 \%$ to $33 \%, 11 \%$ to $36 \%, 4 \%$ to $28 \%, 26 \%$ to $34 \%, 12 \%$ to $22 \%$, and $2 \%$ to $14 \%$ on 29 April, 16 May, 6 June, 19 June, 3 July, and 24 July, respectively. The $\mathrm{N}_{2} \mathrm{O}$ emissions decreased gradually when soil moisture decreased after both waterings. The peak $\mathrm{N}_{2} \mathrm{O}$ flux $(178.6 \mu \mathrm{g}$ $\mathrm{N}_{2} \mathrm{O} \mathrm{m}^{-2} \mathrm{~h}^{-1}$ ) was observed on 19 June, while the corresponding soil WFPS at the $0-12 \mathrm{~cm}$ soil depth (26\% to $34 \%$ ) was much lower than the $45 \%$ to $75 \%$ range. The soil moisture ranges corresponding to peak $\mathrm{N}_{2} \mathrm{O}$ fluxes from soil sample II were lower than from soil sample I; this is possibly because soil II has poor water retention capacity and soil moisture varies more quickly (Li et al., 2008). This result also implied that the production of $\mathrm{N}_{2} \mathrm{O}$ emissions was influenced by soil texture and moisture content (Kallenbach et al., 2010; Cai et al., 2012). For the SUW treatments, $\mathrm{N}_{2} \mathrm{O}$ emissions were likely to follow a similar diurnal pattern among different sampling dates (Figures 2a, 2b, and 2c), and WFPS at the $0-12 \mathrm{~cm}$ soil depth at peak time had a relatively wider range (17\% to $38 \%$ ) than the SW treatment ( $26 \%$ to $34 \%$ ). Additionally, there was little difference between the SW and SUW treatments at the peak time of the diurnal $\mathrm{N}_{2} \mathrm{O}$ emission pattern. The peak time for the SW treatment usually appeared at 12:00 and 16:00 $\mathrm{h}$, which was similar to the results obtained by Xie and $\mathrm{Li}$ (2005). However, peak values always appeared at 12:00 and 16:00 $\mathrm{h}$ after the first watering and at 14:00 $\mathrm{h}$ after the second watering in the SUW treatments.

The influence of soil moisture on greenhouse gas emissions was usually simulated in the models based on soil profile moisture content (generally in terms of WFPS) calculated as the process of water infiltration under SU water application (either rainfall or irrigation) (Li et al., 1992). These models cannot simulate the influence of soil moisture distribution on greenhouse gas emissions from soil under an
SUW application. Furthermore, the relationships between soil moisture and greenhouse gases emissions in the models can also differ between two different water application regimes. The soil moisture variation can have a great impact on the soil heating process, which can also be the main cause of the differences in the diurnal changes in $\mathrm{N}_{2} \mathrm{O}$ emissions. This should be considered in future research.

\section{Implications for sampling protocols}

The $\mathrm{N}_{2} \mathrm{O}$ emissions varied diurnally (Figures 1 and 2); this means that the error in the daily $\mathrm{N}_{2} \mathrm{O}$ emission estimate was not negligible if observations were random. For example, sampling at approximately solar noon (either at 12:00 or 14:00 h) would overestimate the daily mean $\mathrm{N}_{2} \mathrm{O}$ emissions by a mean of $1.7 \%$ to $282.1 \%$ for soil sample I and $8.6 \%$ to $226.7 \%$ for soil sample II. In this study, $\mathrm{N}_{2} \mathrm{O}$ fluxes were measured at 07:00, 08:00, 10:00, 12:00, 14:00, 16:00, 18:00, 20:00, 22:00, 01:00, and 03:00 $\mathrm{h}$ where 10:00 $\mathrm{h}$ was usually considered as the routine observation time applied in many research studies (Tian et al., 2012; Cosentino et al., 2012). However, the errors between the fluxes at 10:00 h and the daily mean in soil sample I mainly ranged from $-24.4 \%$ to $58.6 \%$ and $-47.4 \%$ to $66.2 \%$, and varied in soil sample II from $-55.0 \%$ to $47.2 \%$ and $-74.3 \%$ to $85.2 \%$ for the SW and SUW treatments, respectively, which implies that errors in estimating daily mean $\mathrm{N}_{2} \mathrm{O}$ fluxes were not negligible. Fluxes at 10:00 h for all soil sample I treatments overestimated the daily mean on later sampling dates (20 May and 22 July) after each watering, but was occasionally underestimated on other sampling dates (Figure 1). This indicates that $\mathrm{N}_{2} \mathrm{O}$ fluxes at 10:00 $\mathrm{h}$ from soil sample I have always underestimated the daily mean when soil WFPS was higher than $45 \%$, and occasionally overestimated it when WFPS was lower than $45 \%$. For soil 
sample II, the daily mean $\mathrm{N}_{2} \mathrm{O}$ fluxes for all treatments after the first and second waterings on 16 May and 19 June, respectively, were lower than the fluxes at 10:00 h, but they were higher than the fluxes on other sampling dates. The daily $\mathrm{N}_{2} \mathrm{O}$ variation patterns and the single best sampling time are not fixed and both varied greatly between different soils or different treatments. The peak time and the best sampling time in most cases depends on soil moisture and available $\mathrm{N}$ and $\mathrm{C}$, as well as the changes in temperature at different depths of $\mathrm{N}_{2} \mathrm{O}$ production (Qiu et al., 2011; Trost et al., 2015). Therefore, the most reasonable single sampling time at which the flux can better represent the daily mean value should be discussed based on more diurnal measurements of $\mathrm{N}_{2} \mathrm{O}$ flux variations to accurately estimate daily $\mathrm{N}_{2} \mathrm{O}$ fluxes. Simultaneously, on the basis of the results, it can be inferred that the most reasonable sampling times might be different under different moisture distribution characteristics.

\section{Difference in $\mathrm{N}_{2} \mathrm{O}$ emissions between soil samples I and II}

Some differences were detected between soil samples I and II in their diurnal patterns and ranges of $\mathrm{N}_{2} \mathrm{O}$ emissions. For soil I, $\mathrm{N}_{2} \mathrm{O}$ fluxes ranged from 39.2 to $3677.4 \mu \mathrm{g} \mathrm{N}_{2} \mathrm{O}$ $\mathrm{m}^{-2} \mathrm{~h}^{-1}$ and fluxes for soil II ranged from 0 to $178.6 \mu \mathrm{g} \mathrm{N}_{2} \mathrm{O}$ $\mathrm{m}^{-2} \mathrm{~h}^{-1}$. The peak $\mathrm{N}_{2} \mathrm{O}$ flux was $178.6 \mu \mathrm{g} \mathrm{N}_{2} \mathrm{O} \mathrm{m} \mathrm{m}^{-2} \mathrm{~h}^{-1}$ for the SW treatment from soil II, which was $5 \%$ of the peak flux for the same treatment from soil sample I. The $\mathrm{N}_{2} \mathrm{O}$ fluxes from soil II were much lower than from soil I because soil I had a higher water retention capacity and a higher organic matter content than soil II, which provided more substrates and a suitable environment for soil microbes to participate in nitrification and denitrification (Liu and Zhao, 2008; Trost et al., 2015). In addition, WFPS in soil II ranged from $2 \%$ to $42 \%$, which was much lower than in soil I (16\% to $73 \%$ ). The optimal soil WFPS range for high $\mathrm{N}_{2} \mathrm{O}$ fluxes in the $\mathrm{SW}$ and SUW treatments from soil I were $46 \%$ to $60 \%$, and $45 \%$ to $64 \%$ WFPS, while the optimal soil WFPS range for peak $\mathrm{N}_{2} \mathrm{O}$ fluxes from soil II had a narrower range of $26 \%$ to $34 \%$ and $17 \%$ to $38 \%$, respectively. The major reasons for this difference might be soil sample II has larger particles, higher permeability, poor water retention capacity, and its moisture level is easily influenced by air temperature (Jiao et al., 2006).

\section{CONCLUSIONS}

The effects of soil moisture vertical distribution patterns on diurnal variation of $\mathrm{N}_{2} \mathrm{O}$ emissions were investigated by conducting incubation experiments. Obvious diurnal patterns of $\mathrm{N}_{2} \mathrm{O}$ emissions in the SW and SUW treatments were detected from both soil samples (soils I and II were silty clay and sandy loam, respectively.) with peak $\mathrm{N}_{2} \mathrm{O}$ fluxes mainly appearing in the afternoon (12:00 to 18:00 h). Different vertical watering patterns resulted in changing daily range of $\mathrm{N}_{2} \mathrm{O}$ fluxes and peak time; moisture distribution patterns in SUW soils could be effective in mitigating $\mathrm{N}_{2} \mathrm{O}$ emissions. The different soil texture and $\mathrm{N}$ content level might account for the differences in the magnitude of $\mathrm{N}_{2} \mathrm{O}$ fluxes from soils. Soil moisture for peak $\mathrm{N}_{2} \mathrm{O}$ fluxes in the $\mathrm{SW}$ treatment were within a relatively narrower range of $46 \%$ to $60 \%$ WFPS for soil sample I and $26 \%$ to $34 \%$ WFPS for soil sample II than in the SUW treatments with $45 \%$ to $64 \%$ WFPS and $17 \%$ to $38 \%$ WFPS for soil samples I and II, respectively, even though surface soil moisture for peak $\mathrm{N}_{2} \mathrm{O}$ fluxes differed somewhat from the previously reported optimal soil moisture range of $45 \%$ to $75 \%$ WFPS. The errors between fluxes at approximately 10:00 $\mathrm{h}$ and daily means were not negligible, and the most reasonable single sampling time should be discussed based on more diurnal measurements of $\mathrm{N}_{2} \mathrm{O}$ flux variations.

\section{ACKNOWLEDGEMENTS}

This research was financially supported by the National Natural Science Foundation of China (nr 51179051 and 51209066), Fundamental Research Funds for the Central Universities (nr 2014B37914), and Advanced Science and Technology Innovation Team in Colleges and Universities in Jiangsu Province.

\section{REFERENCES}

Alves, B.J.R., K.A. Smith, R.A. Flores, A.S. Cardoso, W.R.D. Oliveira, C.P. Jantalia, et al. 2012. Selection of the most suitable sampling time for static chambers for the estimation of daily mean $\mathrm{N}_{2} \mathrm{O}$ flux from soils. Soil Biology and Biochemistry 46:129-135.

Bateman, E.J., and E.M. Baggs. 2005. Contributions of nitrification and denitrification to $\mathrm{N}_{2} \mathrm{O}$ emissions from soils at different water-filled pore space. Biology and Fertility of Soils 41:379-388.

Beare, M.H., E.G. Gregorich, and P. St-Georges. 2009. Compaction effects on $\mathrm{CO}_{2}$ and $\mathrm{N}_{2} \mathrm{O}$ production during drying and rewetting of soil. Soil Biology and Biochemistry 41:611-621.

Cai, Y. J., W.X. Ding, and J. Xiang. 2012. Factors controlling $\mathrm{N}_{2} \mathrm{O}$ and $\mathrm{NO}$ emissions from agricultural soils and their influencing mechanisms: A review. Soils 44:881-887.

Castellano, M.J., J.P. Schmidt, J.P. Kaye, C. Walker, C.B. Graham, H. Lin, et al. 2010. Hydrological and biogeochemical controls on the timing and magnitude of nitrous oxide flux across an agricultural landscape. Global Change Biology $16: 2711-2720$.

Cosentino, V.R.N., P.L. Fernandez, S.A.F. Aureggi, and M.A. Taboada. 2012. $\mathrm{N}_{2} \mathrm{O}$ emissions from a cultivated Mollisol: optimal time of day for sampling and the role of soil temperature. Revista Brasileira de Ciência do Solo 36:1814-1819.

Denmead, O.T., J.R. Freney, and J.R. Simpson. 1979. Studies of nitrous oxide emission from a grass sward. Soil Science Society of America journal 43:726-728

Desjardins, R.L., E. Pattey, W.N. Smith, D. Worth, B. Grant, R. Srinivasan, et al. 2010. Multiscale estimates of $\mathrm{N}_{2} \mathrm{O}$ emissions from agricultural lands. Agricultural and Forest Meteorology 150(6):817-824.

Du, R., D. Lu, and G. Wang. 2006. Diurnal, seasonal, and inter-annual variations of $\mathrm{N}_{2} \mathrm{O}$ fluxes from native semi-arid grassland soils of inner Mongolia. Soil Biology and Biochemistry 38(12):3474-3482.

Emery, I., and N. Mosier. 2015. Direct emission of methane and nitrous oxide from switchgrass and corn stover: implications for large-scale biomass storage. Global Change Biology Bioenergy 7:865-876. 
FAO. 2003. World Agricultural Towards 2015/2030: an FAO Perspective. FAO, Rome, Italy.

Horváth, L., B. Grosz, A. Machon, Z. Tuba, Z. Nagy, S.Z. Czóbel, et al. 2010. Estimation of nitrous oxide emission from Hungarian semi-arid sandy and loess grasslands; effect of soil parameters, grazing, irrigation and use of fertilizer. Agriculture, Ecosystems \& Environment 139(1-2):255-263.

Hou, H.J., S.Z. Peng, J.Z. Xu, S.H. Yang, and Z. Mao. 2012. Seasonal variations of $\mathrm{CH}_{4}$ and $\mathrm{N}_{2} \mathrm{O}$ emissions in response to water management of paddy fields located in Southeast China. Chemosphere 89:884-892.

IPCC. 2007. Climate change 2007: mitigation, contribution of Working Group III to the fourth assessment report of the intergovernmental panel on climate change. In Metz, B., O.R. Davidson, and P.R. Bosch (eds.) Cambridge University Press, Cambridge, UK.

IPCC. 2014. Climate Change 2014: Mitigation of Climate ChangeContribution of Working Group III to the Fifth Assessment Report of the Intergovernmental Panel on Climate Change. Cambridge University Press, Cambridge, UK

Jiao, Z.H., A.X. Hou, Y. Shi, G.H. Huang, Y.H. Wang, and X. Chen 2006. Water management influencing methane and nitrous oxide emissions from rice field in relation to soil redox and microbial community. Communications in Soil Science and Plant Analysis 37(13-14):1889-1903.

Kallenbach, C.M., D.E. Rolston, and W.R. Horwath. 2010. Cover cropping affects soil $\mathrm{N}_{2} \mathrm{O}$ and $\mathrm{CO}_{2}$ emissions differently depending on type of irrigation. Agriculture, Ecosystems \& Environment 137:251-260.

Keil, D., P.A. Niklaus, L.R. von Riedmatten, R.S. Boeddinghaus, C.F. Dormann, M. Scherer-Lorenzen, et al. 2015. Effects of warming and drought on potential $\mathrm{N}_{2} \mathrm{O}$ emissions and denitrifying bacteria abundance in grasslands with different land-use. FEMS Microbiology Ecology 91(7):fiv066.

Kennedy, T., C. Decock, and J. Six. 2013. Assessing drivers of $\mathrm{N}_{2} \mathrm{O}$ production in California tomato cropping systems. Science of the Total Environment 465:36-47.

Khalil, M.I., and E.M. Baggs. 2005. $\mathrm{CH}_{4}$ oxidation and $\mathrm{N}_{2} \mathrm{O}$ emissions at varied soil water-filled pore spaces and headspace $\mathrm{CH}_{4}$ concentrations. Soil Biology and Biochemistry 37(10):1785-1794.

Kumar, S., T. Nakajima, A. Kadono, R. Lal, and N. Fausey. 2014. Long-term tillage and drainage influences on greenhouse gas fluxes from a poorly drained soil of central Ohio. Journal of Soil and Water Conservation 69:553-563.

Laville, P., S. Lehuger, B. Loubet, F. Chaumartin, and P. Cellier. 2011. Effect of management, climate and soil conditions on $\mathrm{N}_{2} \mathrm{O}$ and $\mathrm{NO}$ emissions from an arable crop rotation using high temporal resolution measurements. Agricultural and Forest Meteorology 151:228-240.

Li, C.S., S. Frolking, and T.A. Frolking. 1992. A model of nitrous oxide evolution from soil driven by rainfall events: 1 . Model structure and sensitivity. Journal of Geophysical Research 97:9759-9776.

Li, Y.H., F. Wang, R.L. Liu, T.C. Zhao, C. Chen, and Z.L. Yang. 2008. Study on $\mathrm{N}_{2} \mathrm{O}$ emission in the farmland ecosystem of arid areas. Journal of Anhui Agricultural Science 36:15197-15199.

Liu, L. J., H.Y. Bai, G.H. Mu, Q. Ding, and X.X. Li. 2008. Effect of soil texture and environmental factors on farmland $\mathrm{N}_{2} \mathrm{O}$ emission. Journal of Anhui Agricultural Sciences 36:6075-6077.

Liu, B., G.B. Huang, Y.Q. Gao, Q.P. Li, and T. Huang. 2010. Effects of no-tillage on daily dynamics of $\mathrm{CO}_{2}$ and $\mathrm{N}_{2} \mathrm{O}$ emission from spring wheat field during mature stage. Journal of Gansu Agricultural University 45:82-87

Liu, H., and P. Zhao. 2008. Diurnal variations of $\mathrm{N}_{2} \mathrm{O}$ fluxes from soil surface of plantation and orchard in a hilly area of south China. Ecology and Environment 17:1116-1119.

Lu, Y., C.C. Song, and Xu H.W. 2010. Study on diurnal variation of $\mathrm{N}_{2} \mathrm{O}$ fluxes for Calamagrostis angustifolia meadow in Sanjing Plain. Journal of Arid Land Resources and Environment 24(7):176-180.
Metivier, K.A., E. Pattey, and R.F. Grant. 2009. Using the ecosys mathematical model to simulate temporal variability of nitrous oxide emissions from a fertilized agricultural soil. Soil Biology and Biochemistry 41:2370-2386.

Peng, S.Z., S.H. Yang, J.L. Ding, and J.Z. Xu. 2009. Key influencing factors and mitigation measures of nitrous oxide emission from agricultural soil. Journal of Hohai University (Natural Sciences) 37:1-6

Pfab, H., I. Palmer, F. Buegger, S. Fiedler, T. Muller, and R. Ruser. 2012. Influence of a nitrification inhibitor and of placed $\mathrm{N}$-fertilization on $\mathrm{N}_{2} \mathrm{O}$ fluxes from a vegetable cropped loamy soil. Agriculture, Ecosystems \& Environment 150:91-101.

Pimentel, L.G., D.A. Weiler, G.M. Pedroso, and C. Bayer. 2015. Soil $\mathrm{N}_{2} \mathrm{O}$ emissions following cover-crop residues application under two soil moisture conditions. Journal of Plant Nutrition and Soil Science 178:631-64.

Prasad, J.V.N.S., C.S. Rao, K. Ravichandra, C.N. Jyothi, M.B.B.P. Babu, V.R. Babu, et al. 2015. Green house gas fluxes from rainfed sorghum (Sorghum bicolour) and pigeonpea (Cajanus cajan)-Interactive effects of rainfall and temperature. Journal of Agrometeorology 17:17-22.

Qiu, W.H., J.S. Liu, C. X. Hu, X.C. Sun, and Q.L. Tan. 2011. Daily change of nitrous oxide emission from vegetable system. Journal of Huazhong Agricultural University 30:210-213 (in Chinese).

Ravishankara, A.R., J.S. Daniel, and R.W. Portmann. 2009. Nitrous oxide $\left(\mathrm{N}_{2} \mathrm{O}\right)$ : The dominant ozone-depleting substance emitted in the 21st century. Science 326 (5949):123-125.

Scheer, C., R. Wassmann, K. Klenzler, N. Lbragimov, and R. Eschanov. 2008. Nitrous oxide emissions from fertilized irrigated cotton (Gossypium hirsutum L.) in the Aral Sea Basin, Uzbekistan: Influence of nitrogen applications and irrigation practices. Soil Biology and Biochemistry 40:290-301.

Sey, B.K.,A.M. Manceur,J.K. Whalen,E.G. Gregorich, and P. Rochette. 2008. Small-scale heterogeneity in carbon dioxide, nitrous oxide and methane production from aggregates of a cultivated sandy-loam soil. Soil Biology and Biochemistry 40:2468-2473.

Tian, S.Z., T.Y. Ning, S.Y. Chi, Y. Wang, B.W. Wang, H.F. Han, et al. 2012. Diurnal variations of the greenhouse gases emission and their optimal observation duration under different tillage systems. Acta Pedologica Sinica 32:879-888.

Trost, B., A. Prochnow, M. Baumecker, A. Meyer-Aurich, K. Drastig, and F. Ellmer. 2015. Effects of nitrogen fertilization and irrigation on $\mathrm{N}_{2} \mathrm{O}$ emissions from a sandy soil in Germany. Archives of Agronomy and Soil Science 61:569-580.

van der Weerden, T.J., T.J. Clough, and T.M. Styles. 2013. Using near-continuous measurements of $\mathrm{N}_{2} \mathrm{O}$ emission from urineaffected soil to guide manual gas sampling regimes. New Zealand Journal of Agricultural Research 56:60-76.

Wang, G.L., D.L. Chen, and Y. Li. 2010. Effect of soil temperature, moisture and $\mathrm{NH}_{4}{ }^{+}-\mathrm{N}$ concentration on nitrification and nitrificationinduced $\mathrm{N}_{2} \mathrm{O}$ emission. Chinese Journal of Eco-Agriculture 18:1-6.

Wang, B., X.Q. Lee, B.K.G. Theng, J.Z. Cheng, and F. Yang. 2015. Diurnal and spatial variations of soil NOx fluxes in the northern steppe of China. Journal of Environment Sciences-China 32:54-61.

Xia, Y.Q., Y.F. Li, X.B. Li, M. Guo, D.L. She, and X.Y. Yan. 2013. Diurnal pattern in nitrous oxide emissions from a sewageenriched river. Chemosphere 92:421-428.

Xie, J.F., and Y.E. Li. 2005. Effect of soil temperature on $\mathrm{N}_{2} \mathrm{O}$ emission in upland farm of Beijing. Chinese Journal of Agrometeorology 26:7-10.

Yamamoto, A., H. Akiyama, T. Naokawa, and K. Yagi. 2012. Effect of lime-nitrogen application on $\mathrm{N}_{2} \mathrm{O}$ emission from an Andosol vegetable field. Soil Science and Plant Nutrition 58:245-254.

Yao, Z., Z. Zhou, X. Zheng, B. Xie, B. Mei, R. Wang, et al. 2010. Effects of organic matter incorporation on nitrous oxide emissions from rice-wheat rotation ecosystems in China. Plant and Soil $327: 315-330$. 